This article was downloaded by: [Australian National University]

On: 28 September 2011, At: 21:20

Publisher: Routledge

Informa Ltd Registered in England and Wales Registered Number:

1072954 Registered office: Mortimer House, 37-41 Mortimer Street, London W1T 3JH, UK

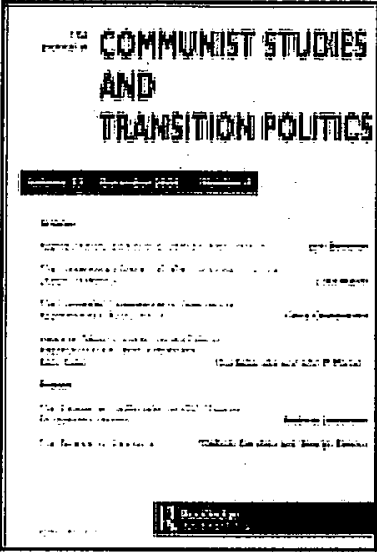

Journal of Communist Studies and Transition Politics

Publication details, including instructions for authors and subscription information:

http://www.tandfonline.com/loi/fjcs20

\title{
Democratization in Russia and the Global Financial Crisis
}

Ian Mcallister \& Stephen White

Available online: 15 Sep 2011

To cite this article: Ian Mcallister \& Stephen White (2011): Democratization in Russia and the Global Financial Crisis, Journal of Communist Studies and Transition Politics, 27:3-4, 476-495

To link to this article: http://dx.doi.org/10.1080/13523279.2011.595159

\section{PLEASE SCROLL DOWN FOR ARTICLE}

Full terms and conditions of use: http://www.tandfonline.com/page/ terms-and-conditions

This article may be used for research, teaching, and private study purposes. Any substantial or systematic reproduction, redistribution, reselling, loan, sub-licensing, systematic supply, or distribution in any form to anyone is expressly forbidden.

The publisher does not give any warranty express or implied or make any representation that the contents will be complete or accurate or up to date. The accuracy of any instructions, formulae, and drug doses should be independently verified with primary sources. The publisher shall not be liable for any loss, actions, claims, proceedings, demand, or costs or 
damages whatsoever or howsoever caused arising directly or indirectly in connection with or arising out of the use of this material. 


\title{
Democratization in Russia and the Global Financial Crisis
}

\author{
IAN MCALLISTER AND STEPHEN WHITE
}

In principle, new democracies should be at greater risk from economic crisis than established ones. And without a popular reservoir of good will for democracy, and in the absence of an electorate that has had extended experience of distinguishing between the government and the political system as a whole, they are at particular risk. The impact of the 2008-9 global financial crisis in post-communist Russia suggests that this may not apply universally. In fact, public support for democratic values has been relatively unaffected by the crisis, in spite of its direct effects on the lives of many ordinary Russians. This may be explained by a history of economic crises and a tradition of 'getting by' when such crises erupt; a greater popular preoccupation with who holds public office than with how effectively they govern; and the lack of a competitive party system, including an effective opposition.

Democracy rests on popular support, passed from generation to generation, for the institutions and procedures that allow it to function effectively. In turn, popular support for democracy depends on benign economic conditions; indeed, early studies of democracy argued that economic modernization was a pre-requisite. ${ }^{1}$ More recent studies have suggested that it is less economic prosperity that promotes democracy than the absence of economic shocks. If economic conditions remain positive, then more regimes will survive, and more of them will be democracies. ${ }^{2}$ Once a reservoir of popular support for democracy has accumulated, the system is more resilient to economic crises and unexpected shocks. The experience of twentieth-century Europe is replete with examples of democracies that collapsed because of economic failure, of which the Weimar Republic in Germany is perhaps the best known; but there are many others in Africa and Latin America. ${ }^{3}$

Ian McAllister is Distinguished Professor of Political Science at the Australian National University in Canberra. His most recent book is The Australian Voter: Fifty Years of Change (2011). Stephen White is James Bryce Professor of Politics at the University of Glasgow, and holds concurrent positions at the Johns Hopkins Bologna Center and the Institute of Applied Politics in Moscow. His most recent book is Understanding Russian Politics (2011).

Journal of Communist Studies and Transition Politics, Vol.27, Nos.3-4, September-December 2011, pp.476-495

ISSN $1352-3279$ print/1743-9116 online

DOI: $10.1080 / 13523279.2011 .595159$ (C) 2011 Taylor \& Francis 
Scholars have taken different views of the extent to which it is appropriate to regard contemporary Russia as a democracy of this kind, with or without adjectives. ${ }^{4}$ But even the Soviet system had rested on a 'social contract' between regime and society, in which stability depended on the provision of a modest and steadily improving standard of living. ${ }^{5}$ Although its postcommunist successor provided much greater opportunities for electoral challenge, it too depended - especially under the Putin presidency - on a high rate of economic growth that allowed a rapid improvement in living standards from which all sections of the society could beniefit: the poor as well as the rich, the periphery as well as the capital cities, civilians as well as the armed forces. The global financial crisis (GFC) of 2008-9 was accordingly a major threat to the Russian system, coming at a time when economic conditions had been improving continuously for almost a decade.

The discussion that follows focuses on the impact of the GFC on Russian public opinion, with particular attention to its impact on public support for democracy as a normative ideal. The first section examines the performance of the Russian economy from the early 1990s; the second section outlines the background to economic voting and proposes two main hypotheses. Trends in public opinion are outlined in the third section, while the fourth and fifth sections use a national survey conducted for the authors in early 2010, shortly after the Duma election that had taken place the previous December, to test the two main hypotheses. In the conclusion we speculate about some explanations that might account for our findings.

\section{Patterns of Economic Performance}

Although the Soviet economy had lagged behind its international competitors for many years before the collapse of communist rule in 1991, the progressive dismantling of the financial subsidies that were integral to the command economy had a devastating impact on individual living standards over the years that followed. In 1989, Russian GDP stood at $\$ 13,066$ per capita (here and elsewhere we use World Bank figures expressed in purchasing power parities and constant prices); throughout the 1990s it declined consistently, bottoming at $\$ 7,829$ in 1999 , just after a rouble crisis in which the Russian government defaulted on its international obligations and the national currency lost much of its value on foreign exchanges. This was a very sharp fall in the real incomes of ordinary Russians, in what appeared to be a direct consequence of the transition to a market economy; vulnerable groups - pensioners, rural workers, parents with large families - suffered disproportionately. ${ }^{6}$

The figures for the GDP growth rate in Figure 1 tell the same story of continuous economic decline from 1990 to the end of the 1990s. Over the decade 
FIGURE 1

GDP GROWTH IN RUSSIA, $1990-2010$

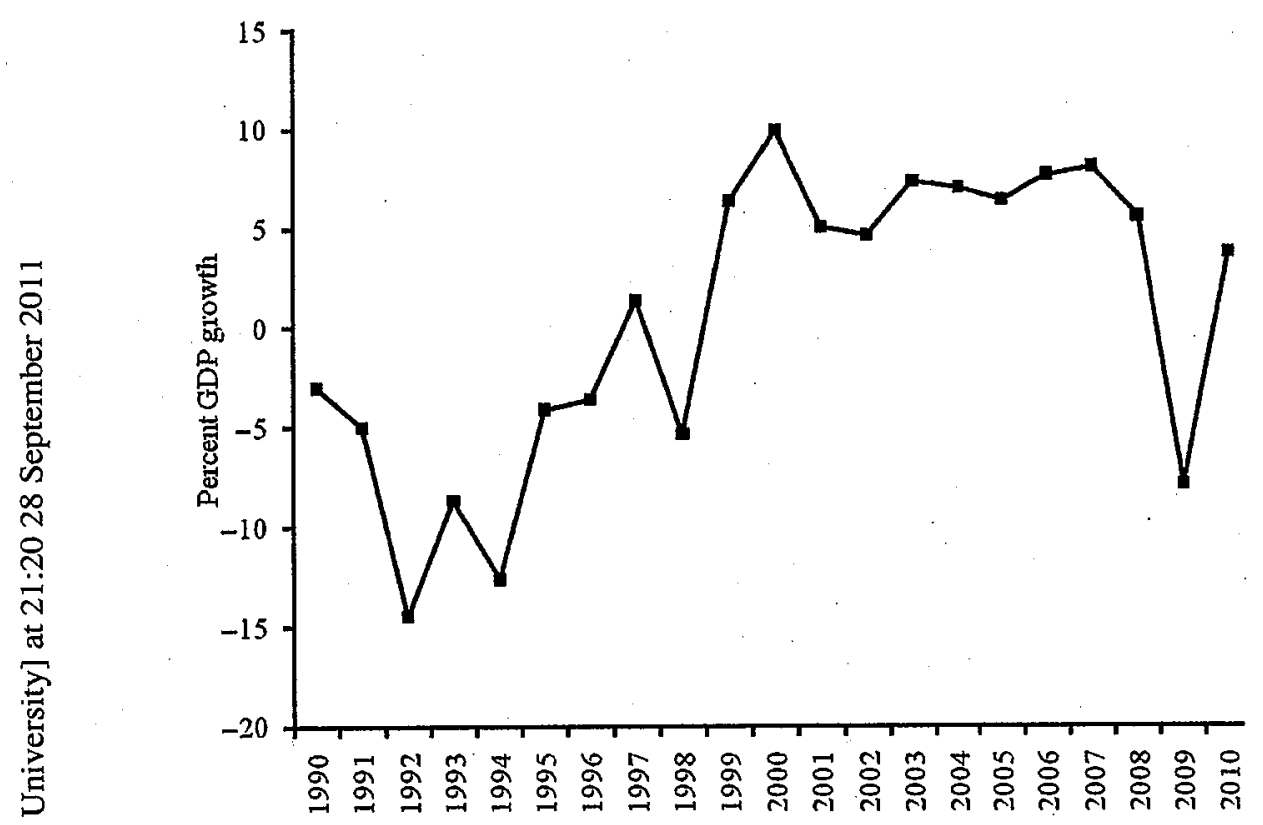

Source: Derived from World Bank Development Indicators, available at < http://www.worldbank. org >, last accessed 18 May 2011; the figure for 2010 is estimated.

the average annual decline was just over 5 per cent; a slight improvement in 1997 was followed by a sharp fall the following year as the currency crisis took effect. The contractions were cumulative, which meant that GDP had fallen by the late 1990s to not much more than half its level in the last years of the Soviet era - a remarkable decline in a relatively short period, of a magnitude that is usually found only in countries suffering defeats in war or a catastrophic natural disaster. It was worse, in fact, than the USSR had experienced in the devastation that had taken place during the Second World War, the First World War or the civil war that had followed the October revolution; scholars compared it with the 'worst catastrophes in Russian history', reaching as far back as the Mongol occupation of the thirteenth and fourteenth centuries. ${ }^{7}$

To cope with the economic breakdown, most Russians were forced to use the informal economy, and to rely on barter and the exchange of goods in order to survive. ${ }^{8}$ The informal economy was also a way of avoiding the use of money; with inflation running at 874 per cent in 1993 alone, money, at least 
in roubles, had little value. ${ }^{9}$ Surrogates came into increasingly widespread use: workers at a Penza clock factory were offered toilet paper (one of them tried to pay her rent in the same unconventional currency, but without success); male workers were offered brassieres; teachers in the Altai region were offered vodka after they had turned down funeral accessories. ${ }^{10}$ There were particular difficulties with state benefits of all kinds, including pensions, with delays of up to three months. 'You might just as well lie down alive in your grave', Valentina Korchenkova from the Tver' region told Izvestiya despairingly. Heart attacks and hysteria were becoming 'routine', as elderly citizens stood in line for their state benefits; and you 'couldn't feed people on promises. ${ }^{11}$

The rouble crisis of August 1998 marked a further turning point in Russian economic fortunes. Declining prices for oil and gas, coupled with a general crisis of confidence and a fear among international investors that Russia would default on its debts, resulted in a major devaluation of the currency. Prices rose sharply (food by 40 per cent in September alone); real incomes fell by about a third; and many Russians, particularly the embryonic middle class, found their savings had lost most of their value or disappeared entirely (even the former Soviet president, Mikhail Gorbachev, was left penniless). ${ }^{12}$ But devaluation increased the price of imports and assisted exports in the domestic industries that had survived the transition to a market economy. This boost to exports, coupled with rising energy and resource prices in 1999 , resulted in a remarkably speedy economic recovery. From 1998 to 1999 GDP growth reversed more than 10 percentage points, and between 1999 and 2008, growth averaged about 7 per cent annually.

Patterns of unemployment largely track these macro-economic trends. While there had officially been no unemployment under communist rule, at least until labour exchanges were reintroduced in July $1991,{ }^{13}$ the shift towards private ownership and closer integration into the international economy meant that the level of participation in the labour force became increasingly dependent on external circumstances. Figure 2 shows that in 1992, just after the collapse of communist rule and the end of notional full employment, the unemployment rate stood at 5.3 per cent. As privatization of the economy gathered pace the rate progressively increased, peaking at 13.4 per cent in 1998. But as economic conditions improved it fell back gradually to the levels that had been experienced at the end of the communist period, dropping to 6.1 per cent in 2007, just before the international crisis (all these figures concealed a considerable spread across the regions; in some cases, particularly in the predominantly Muslim south, unemployment could reach 50 per cent or more). ${ }^{14}$

The GFC had a major impact on all of these indicators, and at all levels. Figure 1 shows that growth dropped by 13.5 per cent - from an expansion 
FIGURE 2

UNEMPLOYMENT IN RUSSIA, $1992-2010$

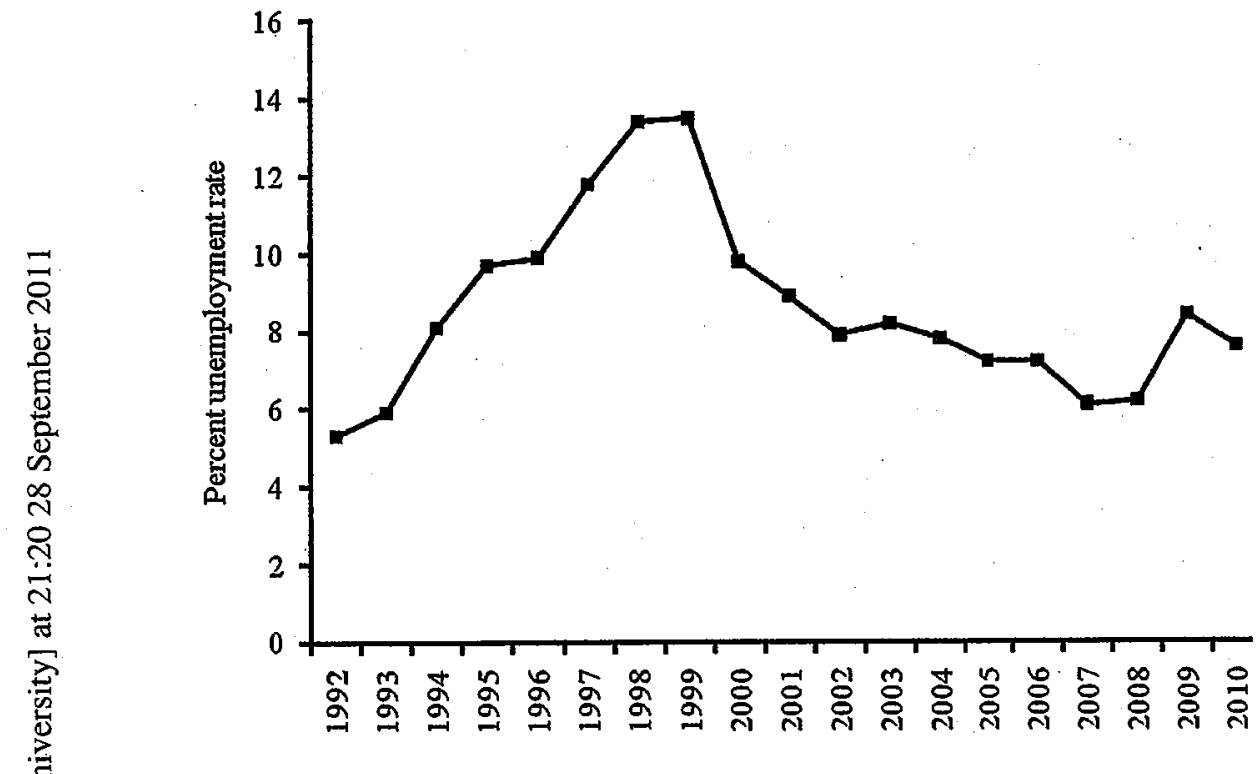

Source: As Figure 1; the figure for 2010 is estimated.

of 5.6 per cent in 2008 to a contraction of 7.9 per cent in 2009 (by contrast, the total contraction of the British economy between 2008 and 2009 is estimated at 5 per cent). Growth returned in 2010, but at a modest 4 per cent that was not quite enough to restore pre-crisis levels of output. ${ }^{15}$ Unemployment had meanwhile increased from 6.2 to 8.4 per cent, the highest level for almost ten years, and GDP per capita dropped back from $\$ 14,766$ to $\$ 13,611$. Things were particularly difficult in the 'mono-cities', where the entire town and its social infrastructure depended on a single employer. The closure of a cement factory in the town of Pikalevo (Leningrad region) led hundreds to block the main road in the summer of 2009 , chanting 'Work! Work!' ${ }^{16}$ For Russians who had become used to more than a decade of increasing prosperity, the GFC was a major shock and apparently a return to the collapse in living standards that they had been obliged to endure during the economic dislocation of the 1990s.

The Russian economy has therefore experienced three distinct periods since the end of communist rule. First, there was the transition to a market economy, which effectively came to an end with the rouble crisis of 1998. The devaluation of the currency and spiralling world energy prices led thereafter to a protracted boom which, by 2008 , had lifted average incomes from 
less than twice to more than three times the subsisterice minimum; some became spectacularly rich, but at the same time the proportion living in offcially defined poverty fell by more than half over the same period, and the state pension increased in value although it fell still further behind average wages. ${ }^{17}$ All of this was suddenly reversed in the third period, from 2008 onwards, as the international crisis led to a sharp recession followed by a much slower rate of advance. These were major fluctuations within a relatively short period of time, with every reason in the comparative literature for us to expect they would have direct and perhaps far-reaching political consequences. ${ }^{18}$ We explore those consequences next.

\section{Public Opinion and the Economy}

Theories of economic voting emphasize the extent to which citizens will either reward or punish governments at elections for economic performance. In general, governments that deliver prosperity will be re-elected, while governments that preside over economic decline will be punished. We might accordingly expect new democracies that experience economic decline to find that their government is challenged, and that those who challenge it most strongly are those who have seen their economic conditions deteriorate the most sharply. However, the simple nexus between economic performance and political support is mediated in three ways: by target, time-span and attribution. ${ }^{19}$

The first dimension, target, focuses on whether voters are primarily concerned about their own financial situation - what is traditionally termed 'pocketbook' voting or, more recently, egocentric voting - or whether they are more concerned about the performance of the national economy as a whole - what has been termed sociotropic voting. ${ }^{20}$ In general, the research tells us that voters are influenced to a greater extent by their perceptions of the performance of the national economy than by the economic position they are in themselves. ${ }^{21}$ There is, of course, some overlap between egocentric and sociotropic evaluations: voters who feel personally secure may project that positive assessment on to their evaluations of the national economy. Nevertheless, when they are taken together, sociotropic voting is by far the more important component within the target dimension to economic voting.

The second dimension to economic voting, the time-span of the judgement that the person makes, focuses on whether voters make retrospective evaluations about past economic performance or prospective ones. In other words, do voters make judgements about what has happened in the past, or about what they expect to happen in the future if a particular party is elected to government? While the research is not conclusive - much depends on the model that is used, as well as the time period that is under examination - the consensus is that voters are guided more than anything 
else by retrospective rather than prospective judgements of this kind. This accords with how voters are generally understood to evaluate non-economic issues, by examining past events and actions as a guide to the electoral choices they should make for the future.

The third dimension of economic voting is attribution - in other words, whom voters hold responsible for economic performance. In European countries with a long history of government intervention in the economy, this question is easily answered, as economic policies are promoted by the parties that are in government. The question of attribution is more difficult in the USA and some other countries with strong free market traditions and in federal systems in which responsibility for tax- and revenue-raising is shared across different levels of government. Nevertheless, the differences between Europe and the USA on attribution are generally minor, and voters have consistently been found to blame governments for poor economic performance and to reward them for good performance. ${ }^{22}$ We would expect attribution to be even more sharply focused in the case of the GFC, since it has been characterized as a failure of government regulation at least as much as a failure of the market mechanism itself.

While these dimensions to economic voting relate to voting and not to regime support, they have several possible implications for the broader question of how citizens will view the political system as a whole. First, we might expect that those who have been most affected by the GFC will be the most likely to withdraw their support from the present regime. Thus, we would predict that those experiencing economic stress will be less likely to support the democratic political system. Second, such a hypothesis is most likely to be supported if there is clear attribution. In other words, in order to punish the current regime for poor economic performance it has to be identified as primarily responsible for the problem in the first place.

\section{Russian Public Opinion and the GFC}

How did the public react to these difficult economic times? Specifically, given that the period of sustained economic prosperity between 1998 and 2008 was a key element in support for Putin and his United Russia Party, ${ }^{23}$ how far were ordinary Russians prepared to blame their government for what had happened during the GFC? Figure 3 suggests that Russians' sense that the crisis was still building peaked in late 2008 and early 2009, when just over half of those interviewed said that the crisis was still ahead of them; since then it has fallen to about one in four. However, most Russians remain pessimistic: in February 2010 just under one in four thought that the crisis had passed, but 38 per cent thought it was still continuing; in March 2011 the position was very 


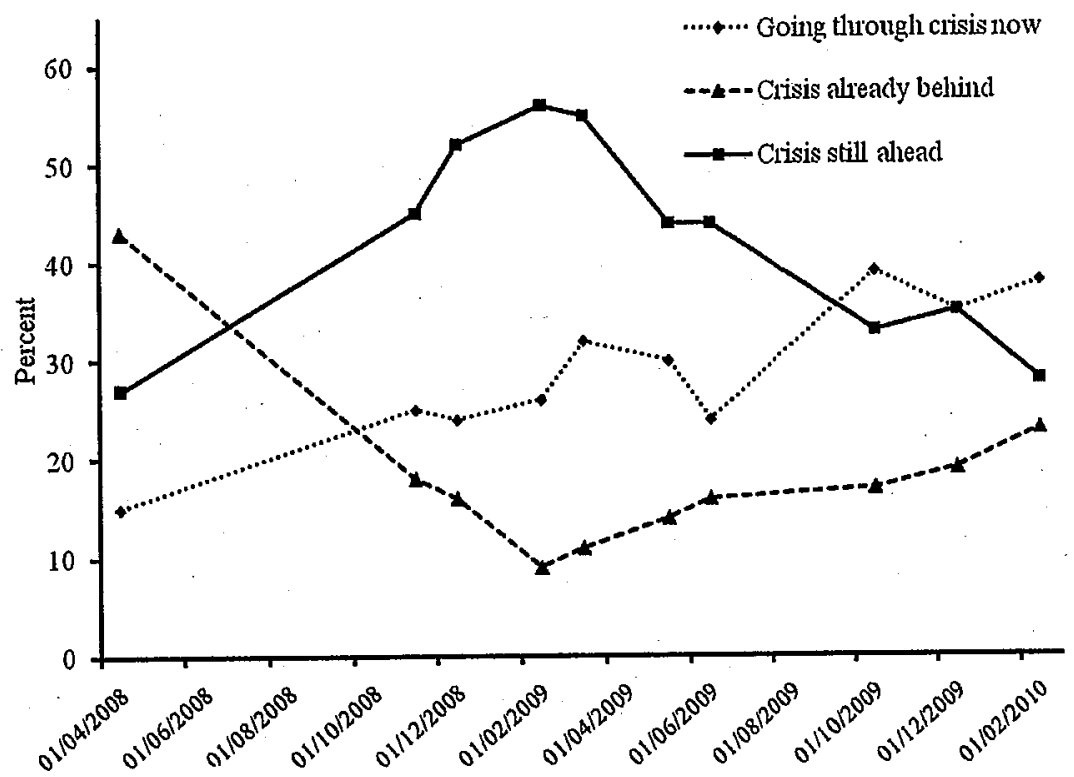

The question wording was: 'What would you say: are we going through the most difficult times, are they behind us, or still ahead?' ('hard to say' not shown).

Source: Adapted from 'Sostoyanie i perspektivy rossiiskoi ekonomiki' [The condition and prospects of the Russian economy], 9 April 2010, available at <http://www.levada.ru/press/ 2010040900.html>, accessed 11 April 2010.

similar, with 26 per cent who thought the crisis had passed and 36 per cent who thought that it was still continuing (Figure 3 ). ${ }^{24}$

A majority of survey respondents were also clear that the GFC had had a serious effect on the daily lives of their own families. In March 2009, a Levada survey found that 49 per cent took this view, compared with 46 per cent who said that the GFC had not had much effect; by September 62 per cent reported a 'very serious effect' on themselves and their families, and in January 2010 there were still 58 per cent who reported a 'very serious effect' on their daily lives and just 38 per cent who said it had made little difference. ${ }^{25}$ Other questions identified the particular respects in which the lives of ordinary citizens had been affected by the continuing crisis. In April 2009, 32 per cent were already experiencing delays in the payment of salaries (by January 2010 this was down to 22 per cent), and 38 per cent were suffering pay cuts (by January 2010 this too had fallen to 22 per cent). In December 2008, 30 per cent were already experiencing job losses or redundancies (this had fallen to 
15 per cent by January 2010) and in March 2009, 20 per cent were experiencing a reduction in their working hours (by January 2010 this was down to 9 per cent). ${ }^{26,27}$

In terms of attributing blame for the crisis, the Levada Centre asked respondents over a series of surveys conducted between 2004 and 2010 whether they thought the government had a 'well-developed economic programme'. The question sought to find out if the public believed policymakers were planning ahead and were therefore anticipating rather than reacting to events. Respondents were generally divided in their opinions, the most common response being that the government did not have a consistent programme of this kind, just 'general ideas'. In only one survey, conducted in December 2007 on the eve of the crisis, did anything approaching a majority opt for a single option, which was that the government did indeed have a coherent programme. In most of the other surveys, opinion was more evenly divided. For example, in March 2010, 31 per cent thought that the government had a coherent programme, 36 per cent thought it had no more than general ideas and 20 per cent thought it was simply reacting to circumstances (Figure 4). ${ }^{28}$

Did ordinary Russians, in any event, believe that government could make a substantial difference to the economic situation in which they found themselves? For many years Russians have looked to government to sustain their living standards, a legacy not just of the command economy that operated during the Soviet era, when the state had all but total control of the nation's resources and managed them directly through a state planning system, but of a longer history of state paternalism. However, the transition to a market economy in the 1990s has served to undermine that view. When asked if the government could improve the economic situation, Figure 5 shows that opinions were again divided. With the exception of the February and June 2009 surveys, more respondents believed that the government could improve the situation than believed it could not, but very similar numbers took an intermediate view.

Trends in public opinion towards the economy and the government's ability to improve it show, at best, ambivalence among the general public. While there is modest optimism that the worst of the crisis may have passed, most Russians regard the government's efforts to improve the situation with some scepticism. The largest numbers see the government as simply reacting to circumstances as they arise and are unconvinced of its ability to intervene effectively in a way that would improve the economic situation. That view may represent a recognition of Russia's integration into the global economy and the limitations on the ability of any national government to act on its own to effect economic change, still more so in the case of a crisis that had affected the Western countries even more severely and whose origins 


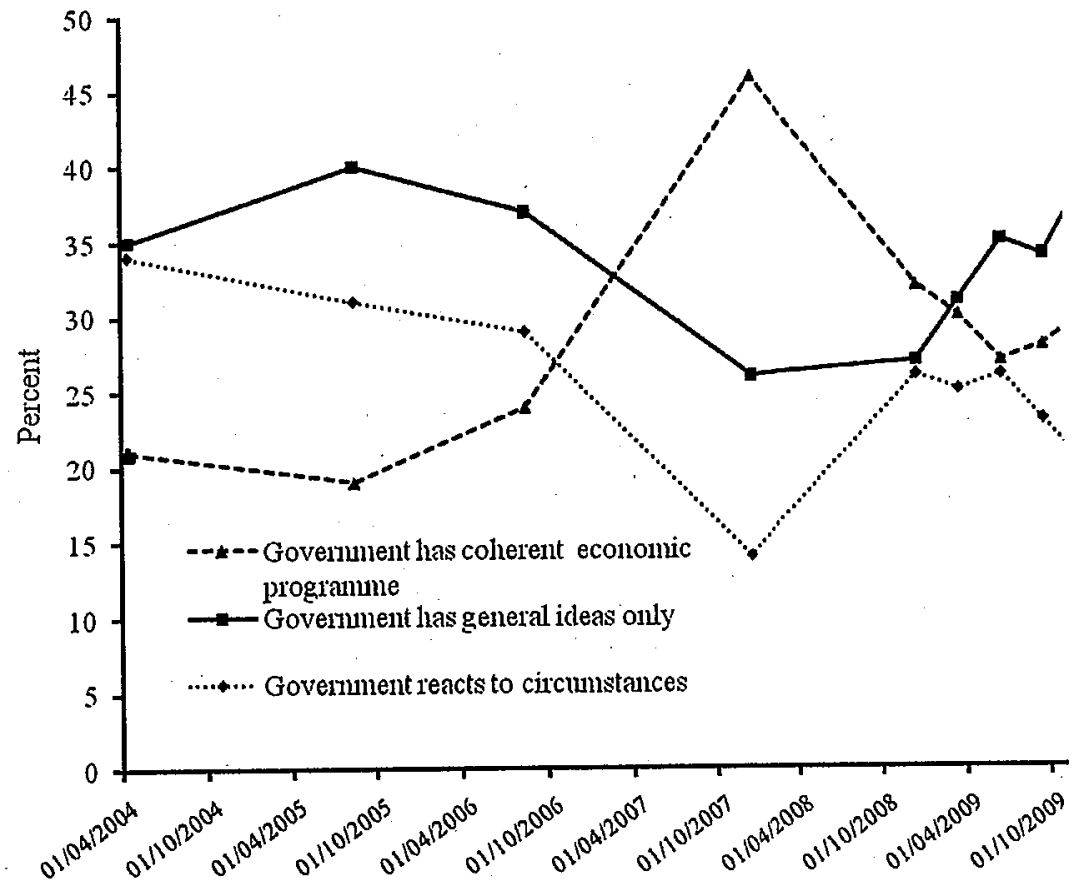

The question was: 'What do you think, does the Russian government have a thought-through economic programme?' The responses were: 'The government has a thought-through economic programme'; 'There is no thought-through programme, it has just some general ideas about what to do in the situation that has arisen'; 'The government has no programme, it just reacts to circumstances' ('hard to say' not shown).

Source: As Figure 3.

appeared to lie entirely outside Russia itself. The most a Russian government could be expected to do in the circumstances was to mitigate its most harmful consequences.

\section{Attributing Blame for the GFC}

In order for the mechanism of rewards and punishment to work effectively, the public must be able to hold a person or a government accountable for their economic performance. This causality works best in larger countries where governments have a tradition of involvement in the economy, such as the Scandinavian countries. It is less obvious in countries that have a more 
FIGURE 5

ABILITY OF GOVERNMENT TO IMPROVE ECONOMIC SITUATION, 2008-10.

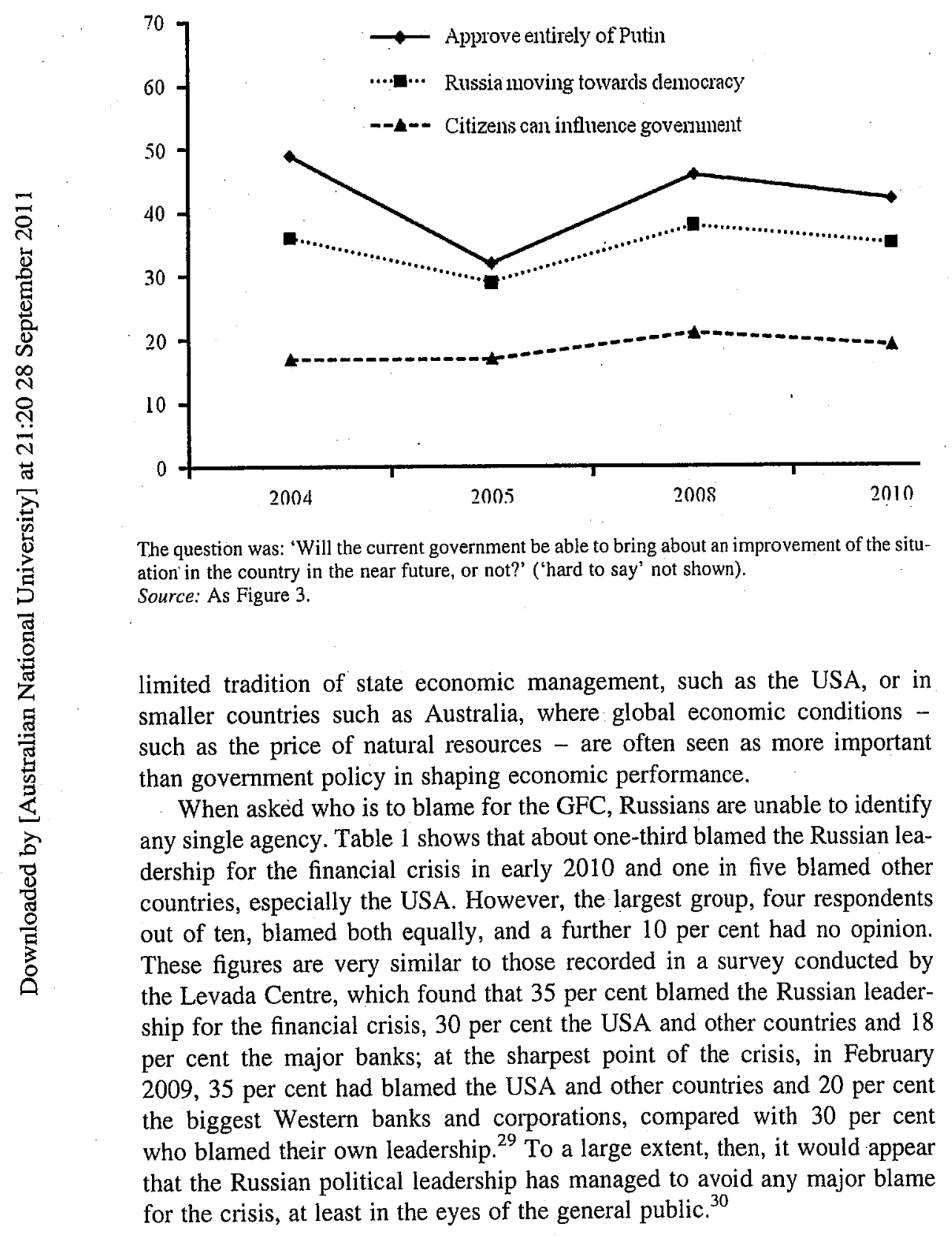


TABLE 1

BELIEFS ABOUT THE GFC

\begin{tabular}{llll}
\hline Blame for GFC & $\%$ & Direction of GFC & $\%$ \\
\hline Russia's leadership & 31 & Crisis has ended & 5 \\
Other countries, especially USA & 19 & Worst is past & 45 \\
Both & 40 & Worse to come & 38 \\
Don't know & 10 & Don't know & 12 \\
Total & 100 & Total & 100 \\
$(N)$ & $(1,862)$ & $(N)$ & $(1,896)$ \\
\hline
\end{tabular}

The questions were: 'A question about the international economic crisis, which also affected our country. Who, in your opinion, is mainly responsible for it?'; 'In your opinion, has the crisis come to an end or is it still continuing?'

Source: Adapted from the authors' 2010 survey (see Appendix).

We might expect that those who were most likely to blame the leadership and take a pessimistic view of the effects of the GFC would be those who had been the most directly affected by it, such as pensioners and parents with large families. We might also expect that respondents who took a more positive view of the national and of their household economy would take a more benign view of whom to blame for the crisis and the direction it had been taking. Table 2 tests these hypotheses by regressing a range of independent variables covering the personal socio-economic background of our respondents and their evaluations of the economy on whether or not they blamed the Russian leadership, and whether or not they believed that worse was still to come. The figures are standardized regression coefficients that show the relative weight of each of the independent variables in predicting blame for the crisis and a belief that it was likely to become even worse.

In terms of whom Russians blame for the crisis, the model explains little; only one relationship is significant, which allows us to conclude that those who believed their household finances to be sound were less likely to blame the leadership of their own country. In that sense, the Russian authorities appear to have avoided any direct responsibility for what has occurred in the economy since 2008. By contrast, pessimistic views about the direction of the crisis were more closely related to both social background and economic opinions. Most important were sociotropic perceptions of the national economy, followed by egocentric views of a person's household economy. Background was also important, with those who enjoyed good living standards being more optimistic, and those who were older and with larger families being more pessimistic.

These results indicate that Russians were more concerned about the course of the crisis, and how it would affect them and their families, than about whom to blame for it, on which opinions were divided. This may well be a legacy of 
TABLE 2

EXPLAINING BLAME FOR AND DIRECTION OF GFC

\begin{tabular}{lll}
\hline & \multicolumn{2}{c}{ Opinion } \\
\cline { 2 - 3 } & Blames Russian leadership & Worse to come \\
\hline Background & & \\
Gender (male) & 0.02 & 0.00 \\
Age & 0.03 & $0.10^{* *}$ \\
Tertiary education & -0.03 & 0.02 \\
Good living standards & 0.01 & $-0.11^{* *}$ \\
Size of family & -0.02 & $-0.06^{*}$ \\
Labour force participant & -0.03 & 0.02 \\
Retrospective economic views & & \\
Country economy better & -0.03 & $-0.15^{* *}$ \\
Household finances better & $-0.09^{* *}$ & $-0.11^{* *}$ \\
Adj $R^{2}$ & 0.01 & 0.09 \\
$(N)$ & $(1,896)$ & $(1,766)$ \\
\hline
\end{tabular}

** Statistically significant at $p<0.01,{ }^{*} p<0.05$ or better, two-tailed.

OLS regression estimates showing standardized (beta) coefficients predicting blame for GFC (coded $3=$ Russian leadership, $2=$ other, $1=$ other countries especially USA) and worse to come (coded $3=$ worse to come, $2=$ worst is past, $1=$ crisis has ended).

Source: As Table 1.

the Soviet era, when coping with shortages of various kinds was a higher priority than seeking to hold the government to account for its economic performance (there was of course no obvious means of doing so), or of the ability of the Russian leadership to represent the crisis as a foreign one in its origins, indeed all but a conspiracy. ${ }^{31}$ It may also be that public attitudes in what is still an evolving system have not developed in the same way as those in the established democracies, where the fortunes of governments are more closely associated with economic performance. In that sense, Russians may blame the system of government itself, rather than the holders of political office; we explore this possibility in the next section.

\section{The Economic Crisis and Attitudes Towards Democracy}

In established democracies, an economic crisis will have implications for the government in office but only rarely for the regime itself. In these countries, democratic values are deeply embedded within the mass electorate and the system will normally have a sufficient stock of good will to weather such shocks. By contrast, countries in the early stages of democratic consolidation; before democratic attitudes have become embedded, are especially vulnerable to economic crises. Many citizens will not have made the distinction between the regime and those who occupy positions of power, and in their desire to 
deliver punishment may conflate the two. Similarly, many older citizens may wish to see a return to the ancien régime and what they may regard as a period of greater stability and prosperity. In short, they may well blame the system itself for poor performance, rather than the incumbent office-holders.

Successive studies have shown that democratic values are only weakly embedded within the post-1989 Russian state. ${ }^{32}$ For example, in our 2010 survey, 21 per cent disagreed with the statement that 'Democracy might have its disadvantages but it is still better than any other form of government', and 14 per cent thought the best form of government for Russia was 'the Soviet system'; a further 33 per cent chose 'a more democratic version' of the Soviet system. Moreover, the election of Vladimir Putin to the presidency in the spring of 2000 led to a series of changes in which an 'executive vertical' - a centralized power structure - was steadily consolidated, strengthening the control of the federal authorities over such key institutions as the media, the judiciary and the electoral system. The result has been to move Russia away from a competitive political system to one that Russian leaders have themselves described as a 'managed', or a 'sovereign' democracy; others preferred not to describe it as a democracy of any kind. ${ }^{33}$

Democracy, as a system of government, is generally understood as encompassing a body of supportive mass beliefs and not simply a set of formal institutions. In order to measure these attitudes, we first of all examine approval of Putin, whose popularity, first as president and then as prime minister, has made him almost a surrogate for the Russian regime. Throughout the 1990s, Putin's popularity actually increased the longer he remained in office, in line with the progressive improvement in Russia's economic fortunes. ${ }^{34}$ Second, we use a question relating to whether or not respondents believed that Russia was moving towards democracy. And third, since feelings of political efficacy are an integral part of the democratic system, we use a question measuring the extent to which the respondents believed that they could influence government decisions. All three of these questions have been asked in previous surveys, and Figure 6 shows the patterns of responses since 2004.

All three measures show a high degree of consistency over the six-year period, with the partial exception of a decline in approval for Putin in 2005 that appears to have been caused by the decision to convert social benefits into what was regarded as inadequate monetary equivalents. By 2008 Putin's popularity had returned to its pre-2005 levels, and two years later 46 per cent 'approved entirely' of his performance as president; a still higher proportion, 78 per cent, 'approved partly or entirely' of his performance and 69 per cent still did so by the spring of 2011, just ahead of Dmitrii Medvedev on 66 per cent. ${ }^{35}$ Beliefs about Russia's progress towards democracy are also consistent over the period; with about four out of every ten respondents believing that the country is moving in that direction. Levels of political. 
FIGURE 6

ATTITUDES TOWARDS DEMOCRACY, 2004-10

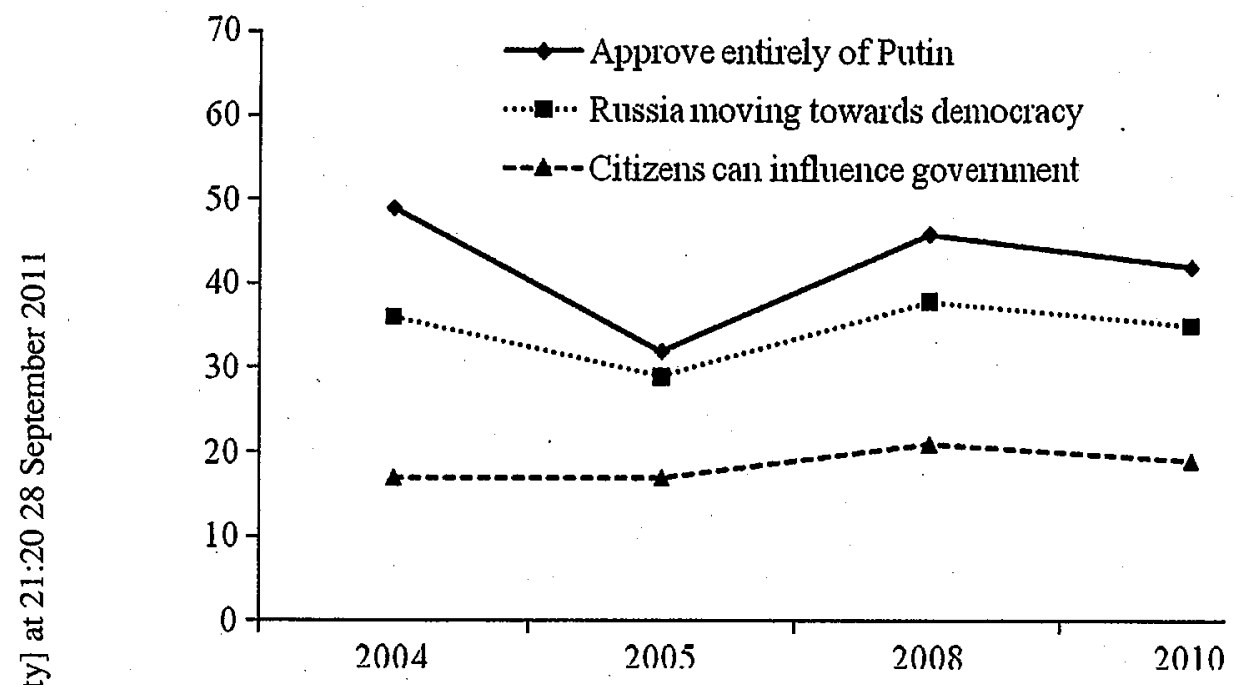

The questions were: 'On the whole, looking back, did you approve or disapprove of the performance of Vladimir Putin as President of Russia?'; 'In your opinion, the course our country has adopted characterizes it as ... a properly formed democracy ... a country steadily moving towards the establishment of democracy ... a country that is more democratic than it was before ... There was more democracy in Soviet times.'; 'To what extent, in your opinion, can people like you have a direct influence on the actions of the central government?' Source: Authors' surveys (see Appendix).

efficacy, however, remain consistently low, with little more than one in five believing they could influence their national government.

To ascertain the role of opinions towards the GFC on attitudes towards democracy, Table 3 regresses blame for the GFC and the direction of the crisis on the three measures. In addition, the model controls for the background characteristics and economic views of the survey respondents. The results show that blaming Russia's leadership for the GFC has an impact only on beliefs about Russia's progress towards democracy: those who blamed the leadership were more pessimistic about democratic progress. Interestingly, blame had no significant impact on approval of Putin, again confirming that the leadership in general, and Putin in particular, has avoided any major responsibility for the GFC. By contrast, beliefs about the future were significantly and strongly related to all three measures of democracy: pessimists were less likely to view Russia as becoming a democracy, to approve of Putin, or to believe they could influence government. 
TABLE 3

THE GFC AND ATTITUDES TOWARDS DEMOCRACY

\begin{tabular}{lccc}
\hline & $\begin{array}{c}\text { Russia becoming a } \\
\text { democracy }\end{array}$ & $\begin{array}{c}\text { Approves of } \\
\text { Putin }\end{array}$ & $\begin{array}{c}\text { Influence on } \\
\text { government }\end{array}$ \\
\hline$G F C$ & $-0.06^{* *}$ & -0.03 & -0.03 \\
Blames Russia's leadership & $-0.11^{* *}$ & $-0.17^{* *}$ & $-0.15^{* *}$ \\
Worse to come & $0.12^{* *}$ & $0.13^{* *}$ & 0.04 \\
Retrospective economic views & 0.05 & -0.02 & $0.07^{* *}$ \\
Country economy better & 0.00 & -0.05 & 0.03 \\
Household finances better & $-0.18^{*}$ & -0.02 & -0.03 \\
Background & 0.03 & 0.01 & 0.02 \\
Gender (male) & $0.07^{* *}$ & 0.01 & $0.13^{* *}$ \\
Age & -0.01 & $0.05^{*}$ & 0.02 \\
Tertiary education & 0.10 & 0.06 & 0.08 \\
Good living standards & & & \\
Large household size & & & \\
Adj $R^{2}$ & & & \\
\hline
\end{tabular}

** Statistically significant at $p<0.01,{ }^{*} p<0.05$.

OLS regression estimates showing standardized (beta) coefficients predicting attitudes towards democracy and government. The dependent variables are coded as follows. Russia becoming a democracy: $4=$ already a fully formed democracy, $3=$ moving towards democracy, $2=$ more democratic than before, $1=$ more democracy in Soviet times; approval of Putin: $4=$ entirely approve, $3=$ somewhat approve, $2=$ somewhat disapprove, $1=$ entirely disapprove; influence on government: $4=$ to significant extent, $3=$ to some extent, $2=$ to an insignificant extent, 1 = no influence at all.

Source: As Table 1

Research, as we have noted, has generally confirmed that sociotropic economic evaluations are more important in determining political behaviour than egocentric beliefs, and this is largely confirmed in Russia. The belief that the country's economy has improved over the previous year is positively related to the view that Russia is moving towards democracy and approval of Putin, although there is no significant relationship with political efficacy. Indeed, for political efficacy, the more important evaluation is an egocentric one - about the respondent's household economy over the previous year. Compared with views about the GFC and economic views, a person's background has a relatively modest effect on all three measures of democracy.

Our original hypotheses predicted, first, that those who had been the most directly affected by the GFC would be the least likely to support the present regime and, second, that the more a respondent blamed the incumbent authorities for the GFC, the more their support for the regime would be likely to be influenced by their evaluation of the economy. There was no support for the first hypothesis: to the extent that economic attitudes mattered in shaping support for the regime, it was in the perceptions of the national 
(sociotropic) economy not the household (egocentric) financial situation. And there was only modest support for the second hypothesis, based on the assumption that Russia's own leadership was to blame for the crisis. In this case the impact was only on support for democracy, not on approval of Putin or political efficacy in general.

\section{Conclusion}

Economic voting in the established democracies is shaped by a distinct set of variables, among which of particular importance are who is most affected by any change, the timescale involved and attribution of responsibility for economic performance. There are variations in how the electorates of the established democracies respond to these three factors, largely (but not exclusively) associated with differences in history, institutions and culture. However, as we noted at the outset, the relationship between performance and reward or punishment is generally uniform. We hypothesized that the relationship might work differently in a new democracy, in this case Russia, where citizens might be more inclined to withdraw their support for competitive politics in response to poor economic performance.

Our findings show only marginal support for this prediction. There are relatively modest effects linking economic performance and support for the principles of democracy, and then only for the national economy, not for the individual's own economic circumstances. Similarly, relatively few see blame for the GFC as resting with the Russian leadership, although it is also the case that a significant number see no obvious sign that it is pursuing a coherent economic strategy. These findings largely coincide with those of Rose and Mishler who, using different measures and data, concluded that the economic crisis had had only a limited impact on popular support for the regime. ${ }^{36}$ Accordingly, to the extent that democracy may be undermined in Russia, it will not be as a consequence of the economic crisis of 2008-9 and its aftermath.

Findings of this kind are difficult to reconcile with the evidence of new democracies that have collapsed because of economic crisis, from the Weimar republic in the early 1930s to Fiji in the 1980s and Bangladesh in the 1990s. Why does Russia appear to be different? Three explanations may be relevant. First, Russia has a history of economic crises, even predating the liberalization of the economy, while shortages and economic stress were common under the command economy of the communist years; scholars were particularly quick to draw comparisons with the rouble devaluation crisis of $1998{ }^{37}$ From that perspective, the GFC of 2008-9 could be seen as the continuation of a much longer trend. Moreover, while dramatic in its impact, the GFC was relatively short-lived. With a history of 'getting by' in such circumstances, Russians could rely on their past skills. Not least, the unemployment rate did not 
increase markedly, suggesting that firms could find ways of dealing with the economic downturn other than shedding workers.

A second possible reason is the absence of an obvious culprit. In the established democracies, blame for the crisis focused on the banks and to a lesser extent on governments for failing to regulate the banks effectively. In Russia, by contrast, Putin maintained his high levels of popularity and our results show that he largely escaped any blame for the crisis. Of course, part of this may reflect Putin's ability to manipulate the mass media and to deflect criticism, but it may also be a consequence of what Rose and Mishler see as the ordinary Russian's preoccupation with who governs at the expense of how effectively government performs. ${ }^{38}$ A third, related factor may be the absence of a stable, competitive party system that offers voters clear and consistent policy choices, and an opposition that is able to hold the government to account. Russia, in these respects, was different; and it was these differences that allowed its leadership to avoid the direct effects of an international economic crisis that had severely tested the stability of its counterparts in other countries.

\section{NOTES}

1. See for example W. W. Rostow, The Stages of Economic Growth (Cambridge: Cambridge University Press, 1961).

2. Adam Przeworski, Michael E. Alvarez, José Antonio Cheibub and Fernando Limogni, Democracy and Development: Political Institutions and Well-Being in the World, 19501990 (Cambridge: Cambridge University Press, 2000).

3. For a review see M. Steven Fish and Jason Wittenberg, 'Failed Democratization', in Christian Haerpfer, Patrick Bernhagen and Ronald F. Inglehart (eds.), Democratization (Oxford: Oxford University Press, 2009).

4. For a review, see Stephen White, Understanding Russian Politics (Cambridge: Cambridge University Press, 2011), pp.321-3.

5. See, for example, Linda J. Cook, The Soviet Social Contract and Why It Failed: Welfare Policy and Workers' Politics from Brezhnev to Yeltsin (Cambridge, MA: Harvard University Press, 1993).

6. Assessments of this kind remain controversial; for some representative views see, for example, Anders Åslund, How Russia Became a Market Economy (Washington, DC: Brookings, 1995), and the more critical judgements of Lawrence R. Klein and Marshall Pomer (eds.), The New Russia: Transition Goes Awry (Stanford, CA: Stanford University Press, 2001), Joseph E. Stiglitz, Globalization and its Discontents (New York: Norton, 2002), and Marshall I. Goldman, The Piratization of Russia: Russian Reform Goes Awry (New York and London: Routledge, 2003). Simon Pirani, Change in Putin's Russia: Power, Money and People (London: Pluto Press, 2010), is also sceptical.

7. R.Kh. Simonyan, Bez gneva i pristrastiya. Ekonomicheskie reformy 1990-kh godov $i$ ikh posledstviya dlya Rossii [Without anger and passion: Economic reforms of the 1990s and their consequences for Russia] (Moscow: Ekonomika, 2010), p. 184.

8. See Richard Rose and Ian McAllister, 'Is Money the Measure of Welfare in Russia?', Review of Income and Wealth, Vol.42, No.1 (1996), pp.75-90.

9. US currency was used extensively (and often illegally) during the 1990s in order to mitigate the effects of hyperinflation. 
10. See respectively Izvestiya, 4 Nov. 1997, p.1 (toilet paper); Argumenty ifakty, 1996, No.47, p.1 (brassieres); Guardian, 23 Sept. 1998, p.15 (vodka).

11. Izvestiya, 2 Aug. 1996, p.2.

12. White, Understanding Russian Politics, p.142.

13. Pravda, 4 July 1991, p.3.

14. The highest levels were in Dagestan ( 20 per cent), Ingushetia ( 47 per cent) and Chechnya ( 53 per cent): 'Rossiiskii statisticheskii yezhegodnik 2008: Statisticheskii sbornik' [Russian statistical annual 2008: Statistical collection] (Moscow: Rosstat, 2008), p.134.

15. Available at <http://www.gks.ru/wps/wcm/connect/rosstat/rosstatsite/main/account/\#>, accessed 20 May 2011.

16. See Stephen Fortescue, 'Putin in Pikalevo: PR or Watershed?', Australian Slavonic and East European Studies, Vol.23, Nos.1-2 (2009), pp.19-38 and B.I. Maksimov, 'Yavlenie Rossii v Pikalevo' [Russia's happening in Plkalevo], Sotsiologicheskie issledovaniya, 2010, No.4, pp. $42-53$.

17. Rossiiskii statisticheskii yezhegodnik 2008, pp.169, 177 (pensioners).

18. The most influential formulation of this approach remains that of James C. Davies, who argued that revolutions were most likely to occur when a population expected living standards to continue to improve but they suffered a sharp reverse: see his 'Towards a Theory of Revolution', American Sociological Review, Vol.27, No.1 (1962), pp.5-19.

19. For reviews, see Michael Lewis-Beck and Mary Stegmaier, 'Economic Determinants of Electoral Outcomes', Annual Review of Political Science, Vol.3 (2000), pp.183-219, and the same authors' 'Economic Models of Voting', in -Russell J. Dalton and Hans-Dieter Klingemann (eds.), Oxford Handbook of Political Behavior (Oxford and New York: Oxford University Press, 2007); Raymond Duch and Randolph T. Stevenson, The Economic Vote: How Political and Economic Institutions Condition Election Results (Cambridge and New York: Cambridge University Press, 2008).

20. Morris P. Fiorina, Retrospective Voting in American National Elections (New Haven, CT: Yale University Press, 1981)

21. The locus classicus is Donald R. Kinder and D. Roderick Kiewiet, 'Sociotropic Politics: The American Case', British Journal of Political Science, Vol.11, No.2 (1981), pp.129-61.

22. Michael S. Lewis-Beck, Economics and Elections (Ann Arbor, MI: University of Michigan Press, 1988).

23. Stephen White and Ian McAllister, 'The Putin Phenomenon', Journal of Communist Studies and Transition Politics, Vol.24, No.4 (2008), pp.604-28.

24. Levada Centre, 18-21 March 2011, available at <http://www.russiavotes.org/national_ issues/national_issues_economics.php?S776173303132=4led5bddf5ee003a81 f3d716f46c0 aa5>, accessed 20 May 2011.

25. 'Sostoyanie i perspektivy rossiiskoi ekonomiki' [The condition and prospects of the Russian economy], 9 April 2010, available at <http://www.levada.ru/press/2010040900.html>, accessed 11 April 2010.

26. 'Krizisnye ozhidaniya rossiyan' [Russians' crisis expectations], 2 March 2010, available at <http://levada.ru/press/2010030202.html>, accessed 13 March 2010.

27. Levada Centre figures as reported in <http://www.russiavotes.org/national_issues/ financialcrisis_trends.php $>$, accessed 20 May 2011.

28. 'Sostoyanie i perspektivy rossiiskoi ekonomiki', 9 April 2010.

29. Ibid.

30. This was a considerable change from 1998, when the largest numbers ( 56 per cent) had blamed the 'unsuccessful economic policy of the previous government headed by $V$. Chernomyrdin'; in 2009 the main cause was thought to be the 'international financial crisis' - 46 per cent took this view: M.K. Gorshkov, R. Krumm and N.Ye. Tikhonova (eds.), Rossiiskaya povsednevnost' $v$ usloviyakh krizisa [Russian everyday life in crisis conditions] (Moscow: Al'fa-M, 2009), p. 198.

31. See for example, Nikolai Starikov, Krizis: kak eto delaetsya [The crisis: how it is working out] (St. Petersburg: Lider, 2010). During the 1998 crisis, 27 per cent blamed the 'subversive 
policies of the West'; in 2009, 24 per cent did so, about as many as blamed the previous or the incumbent Russian government: Gorshkov et al. (eds.), Rossiiskaya povsednevnost', p.198.

32. For a representative selection of views see for instance James L. Gibson, 'A Mile Wide But an Inch Deep(?): The Structure of Democratic Commitments in the Former USSR', American Journal of Political Science, Vol.40, No.2 (1996), pp.396-420; Richard Ahl, Harry Eckstein and Philip G. Roeder, Can Democracy Take Root in Post-Soviet Russia? Explorations in State-Society Relations (Lanham, MD: Rowman \& Littlefield, 1998); M. Steven Fish, Democracy Derailed in Russia: The Failure of Open Politics (Cambridge and New York: Cambridge University Press, 2005); Ellen Carnaghan, Out of Order: Russian Political Values in an Imperfect World (University Park, PA: Pennsylvania State University Press, 2007).

33. White, Understanding Russian Politics, pp.355-62.

34. See Daniel Treisman, 'Presidential Popularity in a Hybrid Regime: Russia under Yeltsin and Putin', American' Journal of Political Science, Vol.55, No.3 (July 2011), pp.590-619.

35. See available at <http://www.russiavotes.org/president/presidency_performance_trends. php\#190>, accessed 20 May 2011.

36. See Richard Rose and William Mishler, "The Impact of Macro-economic Shock on Regime Support in Russia', Post-Soviet Affairs, Vol.26, No.1 (2010), pp.38-57.

37. See, for example, A. Navoi, 'Rossiiskie krizisy obraztsa 1998 i 2008 godov: naidi 10 otlichii' [Russian crises of the forms of 1998 and 2008: find ten differences], Voprosy ekonomiki, 2009, No.2, pp. 24-38. This was clearly a good moment to translate Charles Kindleberger's history of world financial crises: Ch. Kindleberger and R. Aliber, Mirovye finansovye krizisy: Manii,paniki $i$ krakhi [World financial crises: manias, panics and crashes] (St. Petersburg: Piter, 2010).

38. Rose and Mishler, 'The Impact', p.48.

\section{Appendix. A Note on Surveys}

2004

Conducted by Russian Research for Stephen White with the assistance of the ESRC. Fieldwork took place between 21 December 1993 and 16 January 2004, $N=2000$. A datafile and other documentation may be consulted at the UK Data Archive, reference SN 5671 .

2005

Conducted by Russian Research for Stephen White with the assistance of the ESRC. Fieldwork took place between 25 March and 24 May 2005, $N=2,000$. A datafile and other documentation may be consulted at the UK Data Archive, reference SN 5671.

2008

Conducted by Russian Research for Stephen White and Ian McAllister with the assistance of the ESRC under grant RES-000-23-2532 and the Australian Research Council. Fieldwork took place between 30 January and 27 February $2008, N=2,000$. A datafile and other documentation may be consulted at the UK Data Archive.

2010

Conducted by Russian Research for Stephen White and Ian McAllister with the assistance of the ESRC under grant RES-062-23-1378 and the Australian Research Council. Fieldwork took place between 12 February and 1 March 2010, $N=2,000$. A datafile and other documentation may be consulted at the UK Data Archive. 